\title{
ARTICLE
}

\section{Survey of radioactive contamination in Fukushima Naka-dori region, Fukushima, Japan}

\author{
Sin-ya Hohara ${ }^{*}$, Masayo Inagaki, Hirokuni Yamanishi, \\ Genichiro Wakabayashi, Wataru Sugiyama and Tetsuo Itoh \\ Kinki University Atomic Energy Research Institute, 3-4-1 Kowakae, Higashi-Osaka city, Osaka, Japan
}

\begin{abstract}
Due to the Fukushima Daiichi Nuclear Plant Accident, a large area of Tohoku \& Kanto regions contaminated with radioactive materials. Kinki University Atomic Energy Research Institute (Kinki Univ. - AERI) started researches for the radioactive contamination in Fukushima Naka-dori region from the early April 2011. As the result of the research, some conditions of the contaminations become clear. The first one is that air dose rate depends on the condition of the ground surface. The second one is that some radioisotopes from Fukushima Daiichi NPP can be easily found in Naka-dori region at April 2011, but the radioisotopes decayed and became negligible at the middle of July 2011 , except for ${ }^{134} \mathrm{Cs} \&{ }^{137} \mathrm{Cs}$. The last one is that the decay of radioactive Cesium at urban area of Naka-dori region is faster than the physical half-life.
\end{abstract}

Keywords: Fukushima Daiichi; radioactive contamination; urban area; dose rate; pave condition

\section{Introduction}

Due to the Tohoku Region Pacific Coast Earthquake and the Tsunami after the earthquake, residual heat removal systems of Fukushima Daiichi Nuclear Power Plant were down at 11 March 2011[1]. The system down caused hydrogen explosions of the reactor buildings, and a large amount of radioactive materials were released to the general environment. The released radioactive materials moved into a large area of Tohoku and Kanto regions with winds, and fall down to the ground with snows and rains. Air dose rates in Tohoku and Kanto regions increased with the radioactive contaminations.

Kinki Univ. - AERI started research of the radioactive contamination condition in the Fukushima Naka-Dori area, and have continued the research. In this paper, research results are described.

\section{Research in Fukushima Naka-dori region}

\subsection{Over view}

2 investigations have been run in this research. The one is the dose rate distribution research. In this research, GPS-linked $\mathrm{NaI}(\mathrm{Tl})$ scintillation counter is used for data taking. Taken data were plotted on Google Earth and conducted trend analysis.

The other is radioactivity measurements for surface soils. Soil samples were collected from ground surface at monitoring point, and were measured with a high pure germanium counter at Kinki Univ. -AERI.

The dose rate distribution research and the soil sample collections have been run at 3 point. First point is Arakawa-Undo Park in Fukushima city, Fukushima prefecture, where is around N 37.745 degree in latitude and E 140.461 degree in longitude. Second point is Hayama Park in Koriyama city, Fukushima prefecture, where is around N 37.395 degree in latitude and E 140.375 degree in longitude. The last point is Kuroiso Park in Nasu-shiobara city, Tochigi prefecture, where is around N 36.976 degree in latitude, E 140.053 degree in latitude. The research points are shown in Figure 1.

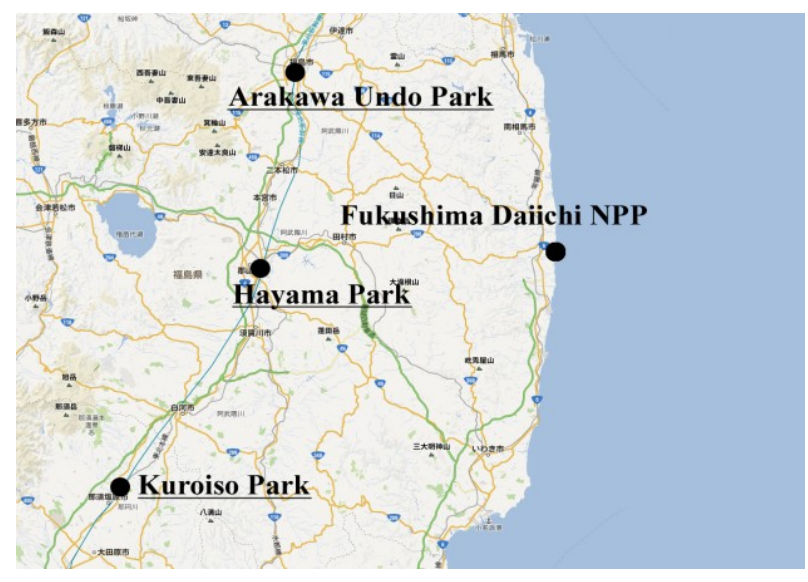

Figure 1. Location of the research points with respect to the Fukushima Daiichi Nuclear Power Plant.

*Corresponding author. Email: hohara@kindai.ac.jp 


\subsection{Dose rate distribution in urban area}

GPS-linked $\mathrm{NaI}(\mathrm{Tl})$ scintillation counter[2], that has been used for dose rate distribution research, is composed of three components. The first component is a radiation detection component. $\mathrm{An} \mathrm{NaI}(\mathrm{Tl})$ survey meter (TCS-171: Hitachi-Aloka Medical co., ltd.) and a microcomputer board (CQ-V850: ESP co., ltd.) are used in this component. The second component is a GPS receiver component. An USB-linked GPS receiver (UMGPS/MF: IODATA DEVICE inc.) is used in this component. (GPS reciever chip is SiRF StarIII.) The last component is a data taking component. An Ultra-Mobile PC (FM-V BIBLO LOOX U/ C30: Fujitsu co., ltd.) is used in this component. The radiation detection component and the GPS reciever component are linked to the data taking component. Dose rate data and GPS data are linked and saved in data taking component. The data taking software was developed and built with Visual C\#/.NET Framework(Microsoft).

The whole system was put in a portable bag, the detection head of the radiation detector was set $50-60$ $\mathrm{cm}$ above the ground, and the measurement was run with walking in about $100 \mathrm{~m} / \mathrm{min}$ speed.

Some results of the measurements are shown in Figure 2 and Figure 3. Figure 2 and 3 shows dose rate distributions around Arakawa-Undo Park. Figure 2 was measured on $17^{\text {th }}$ April 2011, and Figure 3 was measured on $10^{\text {th }}$ August 2012. There is a distribution trend that the dose rate of non-paved area was higher than that of paved area just after the fall out as shown in Figure 2. Some difference of dose rate distribution trend can be found between Figure 2 and Figure 3 in nonpaved area. Dose rate distribution changed widely in non-paved area as shown in Figure 3.

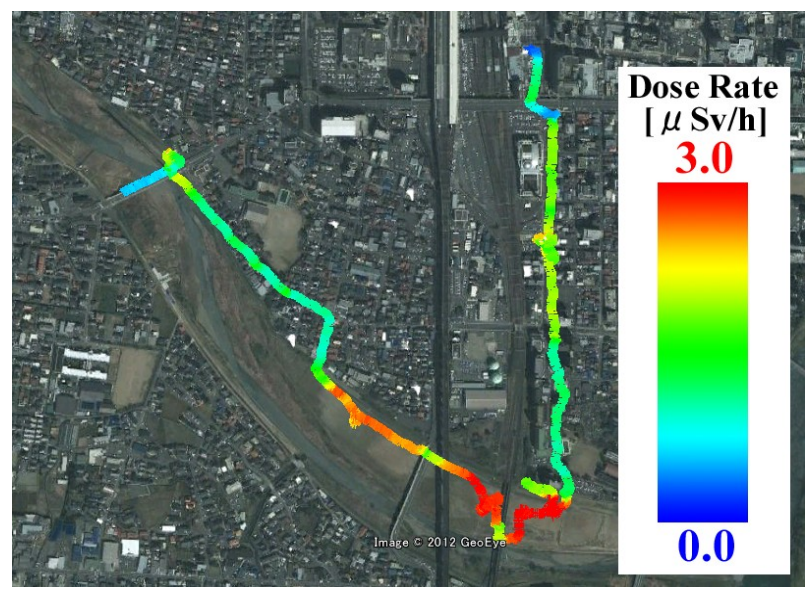

Figure 2. A result of dose rate distribution measurement on $17^{\text {th }}$ April 2011 at Arakawa-Undo Park neighborhood. Line shows a track of the measurement, and line color shows the dose rate. Dose rate of non-paved place is higher than of the paved place.

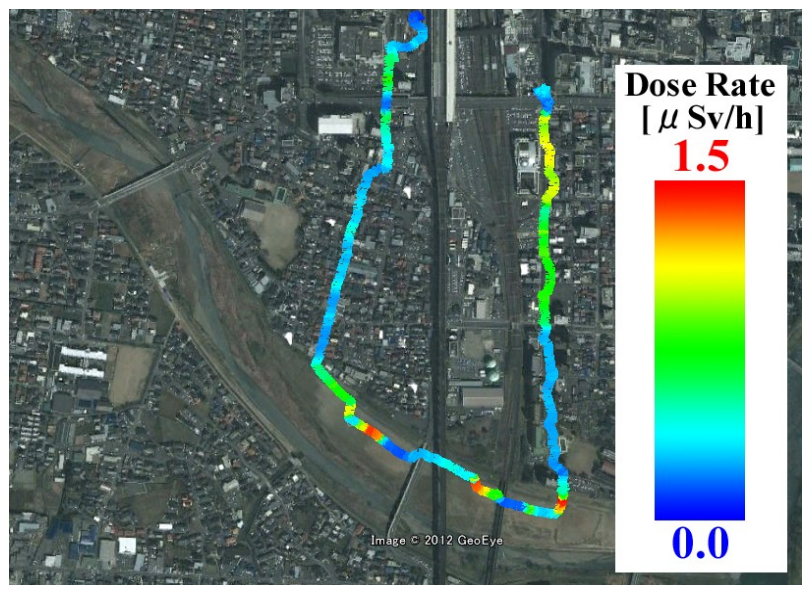

Figure 3. A result of dose rate distribution measurement on $10^{\text {th }}$ August 2012 at Arakawa-Undo Park neighborhood. Line shows a track of the measurement, and line color shows the dose rate. Dose rate distribution changed from the distribution on $17^{\text {th }}$ April 2011.

A photograph of Arakawa-Undo Park is shown in Figure 4. The photograph was taken on $10^{\text {th }}$ Augst 2012 at Arakawa-Undo Park. The dose rate was different with surface condition of the ground. Dose rate of surface soil removed area is lower than that of surface soil non-removed area as shown in Figure 4. This shows that radio isotopes from Fukushima Daiichi NPP exists in the ground surface, and the dose rate in non-paved area depends on a condition of the ground surface.

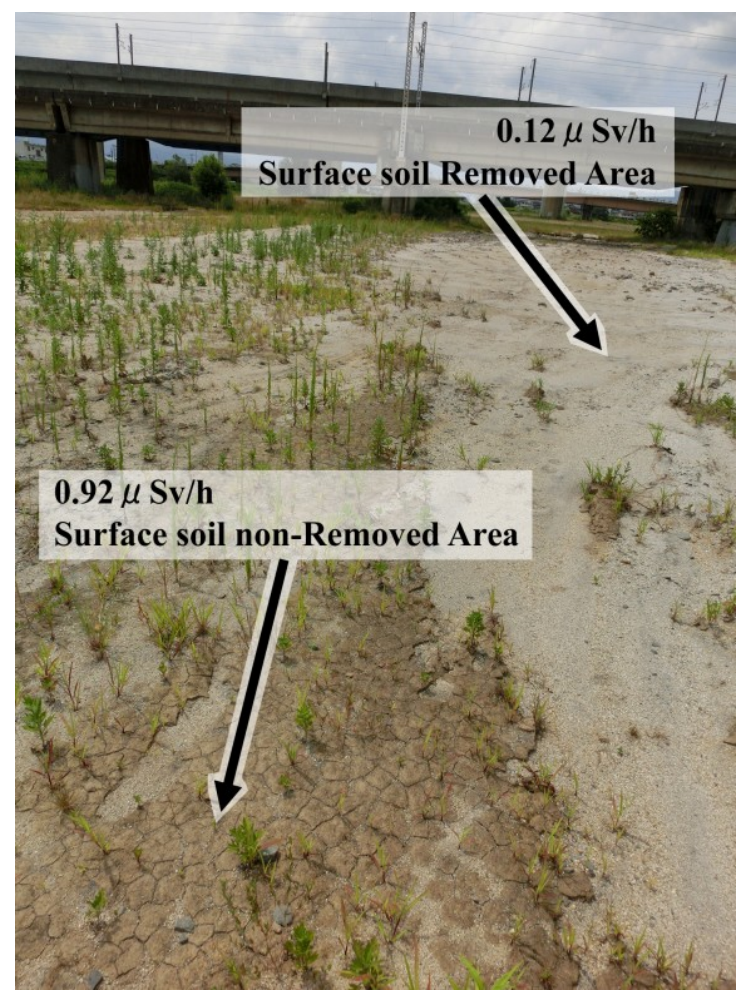

Figure 4. A photograph and dose rates of Arakawa-Undo Park on $10^{\text {th }}$ August 2012. Dose rate is different with surface condition of the ground. 
Table 1. Specific Activity of Soil Samples those collected on $16^{\text {th }}$ and $17^{\text {th }}$ April 2011[3]. Measurements of these samples were run on $18^{\text {th }}$ April 2011. Measurements time was $1800 \mathrm{sec}$ in Live Time for each sample. Specific activities are of $18^{\text {th }}$ April 2011.

\begin{tabular}{ccccc}
\hline nuclide & $\begin{array}{c}\text { Half-life } \\
\text { [day }]\end{array}$ & $\begin{array}{c}\text { Nasushiobara City } \\
\text { Kuroiso Park } \\
{[\mathrm{Bq} / \mathrm{kg}]}\end{array}$ & $\begin{array}{c}\text { Koriyama City } \\
\text { Hayama Park } \\
{[\mathrm{Bq} / \mathrm{kg}]}\end{array}$ & $\begin{array}{c}\text { Fukushima City } \\
\text { Arakawa Undou Park } \\
{[\mathrm{Bq} / \mathrm{kg}]}\end{array}$ \\
\hline${ }^{95} \mathrm{Nb}$ & 35 & $3.26 \mathrm{E} 1 \pm 0.91 \mathrm{E} 1$ & $8.33 \mathrm{E} 1 \pm 1.79 \mathrm{E} 1$ & $1.26 \mathrm{E} 2 \pm 0.28 \mathrm{E} 2$ \\
\hline${ }^{131} \mathrm{I}$ & 8 & $6.49 \mathrm{E} 2 \pm 0.19 \mathrm{E} 2$ & $4.25 \mathrm{E} 3 \pm 0.04 \mathrm{E} 3$ & $2.21 \mathrm{E} 4 \pm 0.01 \mathrm{E} 4$ \\
\hline${ }^{129} \mathrm{Te}$ & 0.048 & $2.31 \mathrm{E} 3 \pm 0.21 \mathrm{E} 3$ & $6.84 \mathrm{E} 3 \pm 0.41 \mathrm{E} 3$ & $2.34 \mathrm{E} 4 \pm 0.07 \mathrm{E} 4$ \\
\hline${ }^{129 \mathrm{~m}} \mathrm{Te}$ & 34 & $3.05 \mathrm{E} 3 \pm 0.32 \mathrm{E} 3$ & $1.06 \mathrm{E} 4 \pm 0.07 \mathrm{E} 4$ & $3.67 \mathrm{E} 4 \pm 0.11 \mathrm{E} 4$ \\
\hline${ }^{132} \mathrm{Te}$ & 3 & $2.98 \mathrm{E} 1 \pm 0.92 \mathrm{E} 1$ & $1.09 \mathrm{E} 2 \pm 0.19 \mathrm{E} 2$ & $2.76 \mathrm{E} 2 \pm 0.34 \mathrm{E} 2$ \\
\hline${ }^{134} \mathrm{Cs}$ & 753 & $4.83 \mathrm{E} 3 \pm 0.04 \mathrm{E} 3$ & $2.11 \mathrm{E} 4 \pm 0.09 \mathrm{E} 4$ & $5.18 \mathrm{E} 4 \pm 0.01 \mathrm{E} 4$ \\
\hline${ }^{136} \mathrm{Cs}$ & 13 & $1.74 \mathrm{E} 2 \pm 0.11 \mathrm{E} 2$ & $6.99 \mathrm{E} 2 \pm 0.22 \mathrm{E} 2$ & $1.80 \mathrm{E} 3 \pm 0.04 \mathrm{E} 3$ \\
\hline${ }^{137} \mathrm{Cs}$ & 11020 & $5.10 \mathrm{E} 3 \pm 0.05 \mathrm{E} 3$ & $2.24 \mathrm{E} 4 \pm 0.10 \mathrm{E} 4$ & $5.50 \mathrm{E} 4 \pm 0.02 \mathrm{E} 4$ \\
\hline
\end{tabular}

Table 2. Specific Activity of Soil Samples those collected on $17^{\text {th }}$ and $18^{\text {th }}$ July 2011 . Measurements of these samples were run on $19^{\text {th }}$ July 2011. Measurements time was $1800 \mathrm{sec}$ in Live Time for each sample. Specific activities are of $19^{\text {th }}$ July 2011.

\begin{tabular}{ccccc}
\hline nuclide & $\begin{array}{c}\text { Half-life } \\
\text { [day] }\end{array}$ & $\begin{array}{c}\text { Nasushiobara City } \\
\text { Kuroiso Park } \\
{[\mathrm{Bq} / \mathrm{kg}]}\end{array}$ & $\begin{array}{c}\text { Koriyama City } \\
\text { Hayama Park } \\
{[\mathrm{Bq} / \mathrm{kg}]}\end{array}$ & $\begin{array}{c}\text { Fukushima City } \\
\text { Arakawa Undou Park } \\
{[\mathrm{Bq} / \mathrm{kg}]}\end{array}$ \\
\hline${ }^{95} \mathrm{Nb}$ & 35 & $<1.40 \mathrm{E} 1$ & $<3.22 \mathrm{E} 1$ & $<5.04 \mathrm{E} 1$ \\
\hline${ }^{131} \mathrm{I}$ & 8 & $<2.27 \mathrm{E} 1$ & $<6.07 \mathrm{E} 1$ & $<9.11 \mathrm{E} 1$ \\
\hline${ }^{129} \mathrm{Te}$ & 0.048 & $<3.12 \mathrm{E} 2$ & $<8.01 \mathrm{E} 2$ & $2.44 \mathrm{E} 3 \pm 0.40 \mathrm{E} 3$ \\
\hline${ }^{129 \mathrm{~m}} \mathrm{Te}$ & 34 & $<4.45 \mathrm{E} 2$ & $<1.13 \mathrm{E} 3$ & $2.92 \mathrm{E} 3 \pm 0.59 \mathrm{E} 3$ \\
\hline${ }^{132} \mathrm{Te}$ & 3 & $<1.62 \mathrm{E} 1$ & $<4.41 \mathrm{E} 1$ & $<6.50 \mathrm{E} 1$ \\
\hline${ }^{134} \mathrm{Cs}$ & 753 & $1.54 \mathrm{E} 3 \pm 0.02 \mathrm{E} 3$ & $1.18 \mathrm{E} 4 \pm 0.01 \mathrm{E} 4$ & $2.56 \mathrm{E} 4 \pm 0.01 \mathrm{E} 4$ \\
\hline${ }^{136} \mathrm{Cs}$ & 13 & $<1.21 \mathrm{E} 1$ & $<2.78 \mathrm{E} 1$ & $<4.37 \mathrm{E} 1$ \\
\hline${ }^{137} \mathrm{Cs}$ & 11020 & $1.72 \mathrm{E} 3 \pm 0.03 \mathrm{E} 3$ & $1.35 \mathrm{E} 4 \pm 0.01 \mathrm{E} 4$ & $2.97 \mathrm{E} 4 \pm 0.01 \mathrm{E} 4$ \\
\hline
\end{tabular}

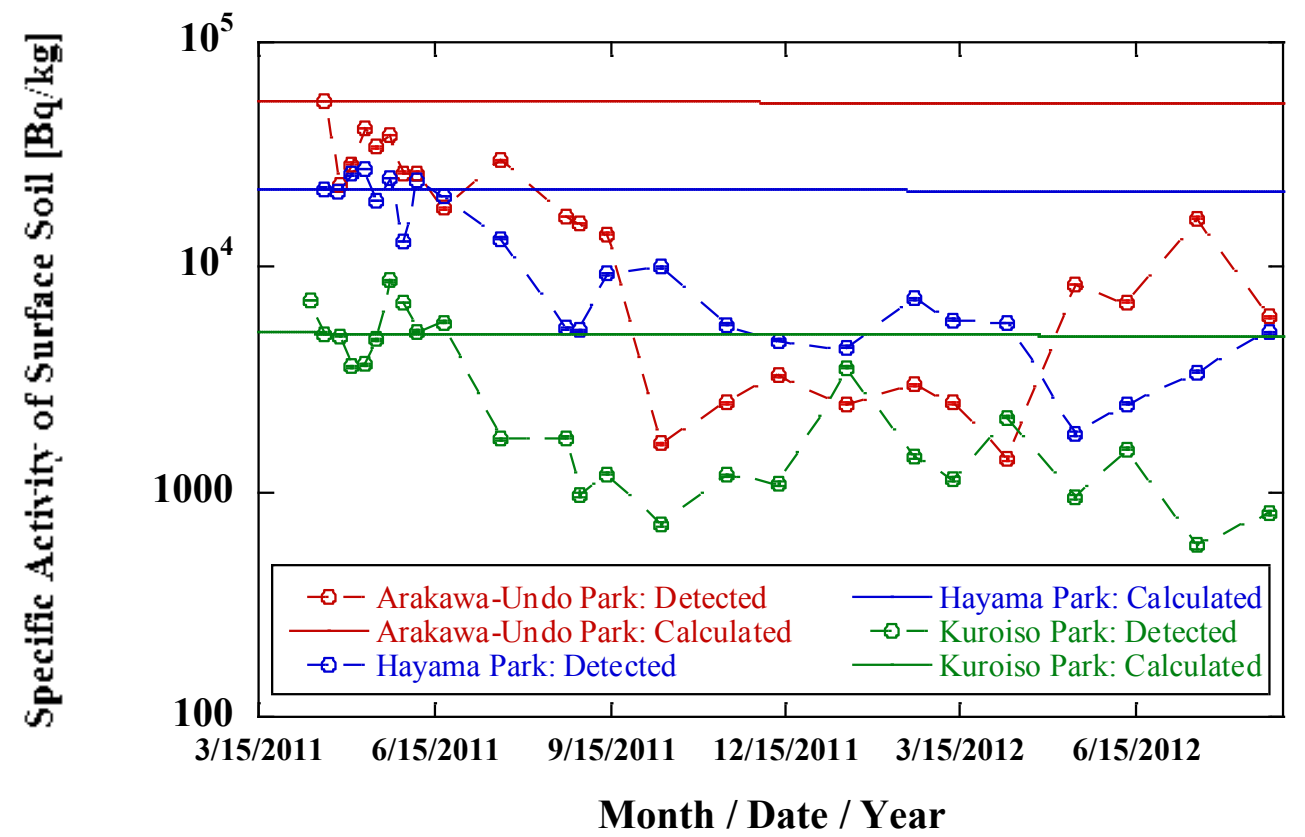

Figure $5 .{ }^{137} \mathrm{Cs}$ activity time trend of the surface soils. Detected activities are lower than calculated activities from the latter half of 2011. Decreasing of ${ }^{137} \mathrm{Cs}$ in surface soils are faster than the physical half-life of ${ }^{137} \mathrm{Cs}$. 


\subsection{Radioactivity time trend of surface soil}

Surface soils for radioactivity measurements were collected at 3 monitoring points as described previously. Soil samples collected from $30 * 30 \mathrm{~cm}^{2}$ area and $1 \mathrm{~cm}$ depth of ground surface. Collected soils were packed in U-8 sample cases. Soil samples were measured with HP-Ge and the measured gamma spectrum analyzed with a nuclide library of ORTEC EG\&G. The measurement time is $1800 \mathrm{sec}$ for each sample. The soil samples were collected once in a week from $17^{\text {th }}$ April 2011 to $4^{\text {th }}$ June 2011 , once in a month from July 2011 to August 2012.

Table 1 and Table 2 show the soil samples' specific activity that was collected at $16^{\text {th }} \& 17^{\text {th }}$ April 2011 and $17^{\text {th }} \& 18^{\text {th }}$ July 2011 . Radio isotopes, those came from Fukushima Daiichi NP, were detected in April 2011. Though almost of the isotopes decayed and became negligible in the middle of July 2011 except for ${ }^{134} \mathrm{Cs}$ and ${ }^{137} \mathrm{Cs}$.

${ }^{137} \mathrm{Cs}$ activity time trend of the surface soils are shown in Figure 5. Break lines show detected activity, and solid lines show ${ }^{137} \mathrm{Cs}$ decay lines calculated from detected activity of $18^{\text {th }}$ April 2011 samples. It is found that the decreasing of ${ }^{137} \mathrm{Cs}$ activity is faster than the physical half-life of ${ }^{137} \mathrm{Cs}$.

\section{Conclusion}

Kinki Univ. - AERI have researched the radioactive contamination in Naka-Dori region, Tohoku area. Some conditions of the contamination became clear as the result of the research. The first point is the trend of the dose rate distribution. Dose rates of non-paved area were higher than those of neighborhood paved area just after the fall out. Though, dose rate distribution changed widely in non-paved area.
The second point is the radioactivity of surface soils in Naka-Dori region. Radioactive nuclides from Fukushima Diichi NPP, ${ }^{95} \mathrm{Nb} 、{ }^{129 \mathrm{~m}} \mathrm{Te} 、{ }^{129} \mathrm{Te} 、{ }^{132} \mathrm{Te} 、{ }^{131} \mathrm{I}$ 、 ${ }^{134} \mathrm{Cs} 、{ }^{136} \mathrm{Cs}$, ${ }^{137} \mathrm{Cs}$ were detected in April 2011, though almost nuclides decayed and became negligible in July 2011 except for ${ }^{134} \mathrm{Cs}$ and ${ }^{137} \mathrm{Cs}$.

The third point is time trend of ${ }^{137} \mathrm{Cs}$ in the surface soils. Activity of ${ }^{137} \mathrm{Cs}$ in surface soils has decreased faster than the physical half-life in Naka-Dori region.

Kinki Univ. - AERI intends to continue the research in Naka-Dori region.

\section{Acknowledgements}

This work is supported by Kinki University and Kinki University Atomic Energy Research Institute.

\section{References}

[1] Nuclear and Industrial Safety Agency, Jishin Higai Jyoukyou, News Release, Dai 8 Hou, Ministry of Economy, Trade and Industry, 12. March 2011. [in Japanese]

[2] S. Hohara and S. Ito, Development of a portable natural background-radiation measurement system equipped with global positioning function and its application, Annual Report of Kinki University Atomic Energy Research Institute 45 (2008), pp.1-10. [in Japanese]

[3] S. Hohara, M. Inagaki, K. Kojima, H. Yamanishi, G Wakabayashi, W. Sugiyama and T. Itoh, Survey of living environmental land contaminated with radioactive materials due to Fukushima Daiichi Nuclear Plant accident, Transactions of the Atomic Energy Society of Japan 10 (2011), pp.145-148. [in Japanese] 